\title{
Recurrent auricular chondritis and cartilage repair
}

\author{
A P Rozin, E Gez, R Bergman
}

Ann Rheum Dis 2005;64:783-784. doi: 10.1136/ard.2004.025726

W present a case of recurrent auricular chondritis, which developed after two injections of a luteinising hormone-releasing hormone (LH-RH) analogue buserelin combined with oral treatment of a pure antiandrogen bicalutamide (Casodex). The patient was treated successfully with a continuous moderate dose of corticosteroids together with azathioprine and methotrexate. Complete repair of the deformed ear followed 7 months after starting the treatment.

Relapsing polychondritis (RP) is a chronic autoimmune cartilaginous inflammation. Auricular chondritis is a presenting sign in over $85 \%$ of patients, in which patients' ears become red, swollen, and tender. We observed a painless form of recurrent auricular chondritis complicated by severe cartilage damage.

\section{CASE REPORT}

A 69 year old man had a history of old myocardial infarction and prostatic adenocarcinoma (Gleason score VI, stage T2B NO MO). He underwent two injections of an LH-RH analogue buserelin (Suprefact Depot, Aventis Pharma), combined with a pure antiandrogen bicalutamide (Casodex; AstraZeneca).

Five months after starting treatment he presented with a painless redness and swelling of his right ear, which spared the lobe. This inflammation, showing inflammatory mononuclear infiltrate, progressed to include dropping and deformity of the upper part of the ear, and resolved spontaneously after 3 months (figs $1 \mathrm{~A}$ and 2). The patient was then referred to the rheumatologist.

Besides the dropped pinna, no systemic manifestations were found on physical examination and the patient's neurological status was unremarkable, including normal pain perception. Retinal screening showed no vasculitic changes. Routine laboratory investigation was normal except for raised inflammatory markers: erythrocyte sedimentation rate and $\mathrm{C}$ reactive protein. Serum immunoelectrophoresis, antinuclear antibodies, antineutrophil cytoplasmic antibodies, rheumatoid factor, prostate-specific antigen were normal. Viral serology, tuberculin test, and Venereal Disease research Laboratory test were negative. Ultrasound of large vessels and echocardiography were normal. A chest $x$ ray examination and computed tomography (CT), abdominal CT, and bone scan were unremarkable.

Owing to serious coronary disease, the lack of active auricular inflammation and systemic disease, and because buserelin treatment had been stopped, it was decided to observe the patient without treatment. However, painless auricular chondritis of the opposite side occurred 3 months later, supporting an initial suspicion of relapsing polychondritis. Prednisone $40 \mathrm{mg} /$ day and azathioprine $100 \mathrm{mg} /$ day were given. Corticosteroids were tapered to $20 \mathrm{mg} /$ day for 1 month after reduction of inflammation in the opposite ear. Azathioprine treatment was stopped when the liver enzyme level was significantly raised after 2 months of treatment. A daily dose of prednisone $20 \mathrm{mg} /$ day was continued, and oral methotrexate $7.5 \mathrm{mg} /$ week was started after the liver function returned to normal. Partial repair of the auricular cartilage was noted 2 months later and full repair of the deformed ear was seen 7 months after the start of corticosteroids and second line treatment (fig 1B). No auricular deformity of the second ear developed.

\section{DISCUSSION}

A case of RP which followed 5 months of antiandrogen treatment with another LH-RH analogue, goserelin (Zoladex) was reported a few years ago. ${ }^{1}$ A hormonal precipitating factor in RP has been suggested by reports of patients whose disease worsened during pregnancy or during chorionic gonadotropin treatment. ${ }^{23}$ However, RP affects men and women equally.

It is still unclear, what component of antiandrogen treatment might be responsible for the auricular chondritis in our case, but the precedent with other LH-RH analogues points to buserelin as possible offender. Is there really a relation with prostate cancer treatment, when only a few cases are reported among the millions who receive this type of treatment? The question should be further investigated.

We think, that deep suppression of the autoimmune process with a moderate dose of prednisone $(20 \mathrm{mg} /$ day $)$ and second line treatment may be the background for effective cartilage repair. ${ }^{4}$ Corticosteroids, carrying androgen properties, might also promote cartilage restoration. ${ }^{56}$ It has been shown that corticosteroids might stimulate glycosaminoglycan and DNA synthesis in chondrocytes. ${ }^{78}$ It is well known that articular cartilage in adults has a limited ability for self repair. However, if the damage extends beyond the subchondral bone, a repair process ensues in which mesenchymal progenitor cells migrate into the injured site and undergo chondrogenic differentiation. ${ }^{9}$ Highly vascularised auricular skin and perichondral tissue may provide the cartilage with such progenitor cells and growth factors. ${ }^{10}$ Painless inflammation of cartilage tissue in the patient with

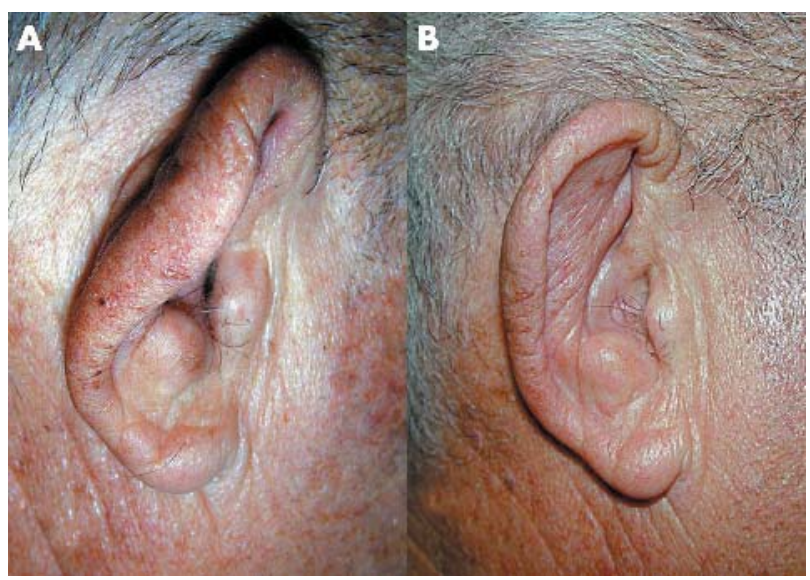

Figure 1 (A) Droop of the pinna after a prolonged (3 months) painless episode of auricular chondritis. The biopsy point is seen on the upper posterior portion of the auricular cartilage. (B) Complete repair of the normal auricular form and cartilage followed 7 months of treatment. 


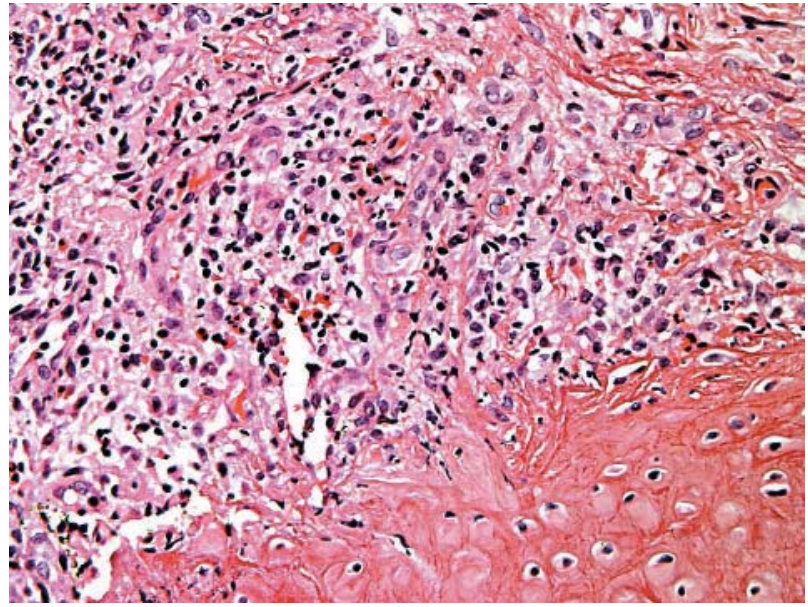

Figure 2 An inflammatory cell infiltrate obscures the chondrodermal interface and partially replaces the auricular cartilage: the findings are associated with RP (haematoxylin-eosin, $\times 400$ ).

normal pain perception may indicate early destruction of receptors. If such occult damage involves cartilage tissue of large vessels, the consequences may be dramatic. This concealed process should be considered in planning follow up and prophylaxis of a flare.

\section{Authors' affiliations}

A P Rozin, B Shine Department of Rheumatology, Rambam Medical Centre and B Rappaport Faculty of Medicine, Israel-Technion Institute of Technology, Haifa, Israel
E Gez, Department of Oncology, Rambam Medical Centre and B Rappaport Faculty of Medicine, Israel-Technion Institute of Technology, Haifa, Israel

R Bergman, Department of Dermatology, Rambam Medical Centre and B Rappaport Faculty of Medicine, Israel-Technion Institute of Technology, Haifa, Israel

Correspondence to: Dr A P Rozin; a_rozin@rambam.health.gov.il

Accepted 18 October 2004

\section{REFERENCES}

1 Labarthe MP, Bayle-Lebey P, Bazex J. Cutaneous manifestations of relapsing polychondritis in a patient receiving goserelin for carcinoma of the prostate. Dermatology 1997; 195:391-4.

2 Gimovsky ML, Nishiyama M. Relapsing polychondritis in pregnancy. A case report and review. Am J Obstet Gynecol 1989;161:332-4.

3 Rogers FD, Lansbury J. Atrophy of auricular and nasal cartilages following administration of gonadotropin in a case of arthritis murilans with the sicca syndrome. Am J Med Sci 1955;229:55-62.

4 Moreland LW, O'Dell JR. Glucocorticoids and rheumatoid arthritis. Arthritis Rheum 2002;46:2553-63.

5 Jo H, Park JS, Kim EM, Jung MY, Lee SH, Seong SC, et al. The in vitro effects of dehydroepiandrosterone on human osteoarthritic chondrocytes. Osteoarthritis Cartilage 2003; 11:585-94.

6 Cicuttini FM, Wluka A, Bailey M, O'Sullivan R, Poon C, Yeung S, et al. Factors affecting knee cartilage volume in healthy men. Rheumatology (Oxford) 2003;42:258-62.

7 Takigawa M, Takano T, Nakagawa K, Sakuda M, Suzuki F. Hydrocortisone stimulation of proliferation and glycosaminoglycan synthesis in rabbit craniofacial chondrocytes in vitro. Arch Oral Biol 1988;33:893-9.

8 Wang J, Elewaut D, Hoffman I, Veys EM, Verbruggen G. Physiological levels of hydrocortisone maintain an optimal chondrocyte extracellular matrix metabolism. Ann Rheum Dis 2004;63:61-6.

9 Kumagai K, Saito T, Koshino T. Articular cartilage repair of rabbit chondral defect: promoted by creation of periarticular bony defect. J Orthop Sci 2003;8:700-6

10 Sanchez M, Azofra J, Anitua E, Andia I, Padilla S, Santisteban J, et al. Plasma rich in growth factors to treat an articular cartilage avulsion: a case report. Med Sci Sports Exerc 2003;35:1648-52.

\section{Cerebral vasculitis as a primary manifestation of systemic lupus erythematosus}

\section{A T Rowshani, P Remans, A Rozemuller, P P Tak}

A 46 year old white man was referred to us because of an 8 week history of severe progressive headache and psychosis. Associated symptoms were minor somnolence, poor concentration, and weight loss of $10 \mathrm{~kg}$ in 3 months. No photosensitivity, fever, or night sweats were reported. Neurological examination was unremarkable. Also, general examination failed to show any abnormality. Especially, no skin abnormalities were apparent. Medical history disclosed an undocumented period of polyarthritis, and for 1 year he had been receiving acenocoumarol because of diagnosed amaurosis fugax.

Laboratory investigation showed a raised erythrocyte sedimentation rate $(30 \mathrm{~mm} / \mathrm{lst} \mathrm{h})$ with a normal $\mathrm{C}$ reactive protein and no signs of anaemia or thrombocytopenia. Leucocyte count was normal with slightly decreased lymphocytes $\left(1.9 \times 10^{9} / 1\right)$. An antinuclear antibody (ANA) test was positive with a homogeneous pattern. A positive Crithidia test confirmed the presence of anti-dsDNA antibodies. Low avidity antibodies to dsDNA were detected (43 U/ml). IgM and IgG antibodies to cardiolipin could be demonstrated. The test for lupus anticoagulants was positive. Both lues serology and HIV test were negative. There were no signs of renal or liver disease. Lumbar puncture showed $115 \times 10^{6}$ leucocytes $/$, containing $95 \%$ lymphocytes. The protein content of the cerebrospinal fluid (CSF) was raised $(5 \mathrm{~g} / \mathrm{l})$ with an increased IgG index (1.06) without oligoclonal bands. Antineuronal and antiribosomal P-peptide antibodies were negative in serum and CSF. Cytological analysis of CSF and also polymerase chain reaction for mycobacterial infections showed no abnormalities. Chest $x$ ray and cardiac ultrasound examinations were normal. Brain magnetic resonance imaging (MRI) showed an increased signal intensity on $\mathrm{T}_{2}$ weighted images in the bilateral white matter and in the basal ganglia, which were progressive on repeat MRI (fig 1). Meningeal involvement could not be seen after contrast administration. Cerebral angiography was normal. Brain biopsy showed vasculitis with mononuclear cells, mainly lymphocytes, infiltrating the whole vessel wall, accompanied by fibrinoid necrosis and deposition of IgG and complement in several vessels (fig 2 ). The diagnosis was neuropsychiatric systemic lupus erythematosus (NPSLE) due to cerebral vasculitis. 

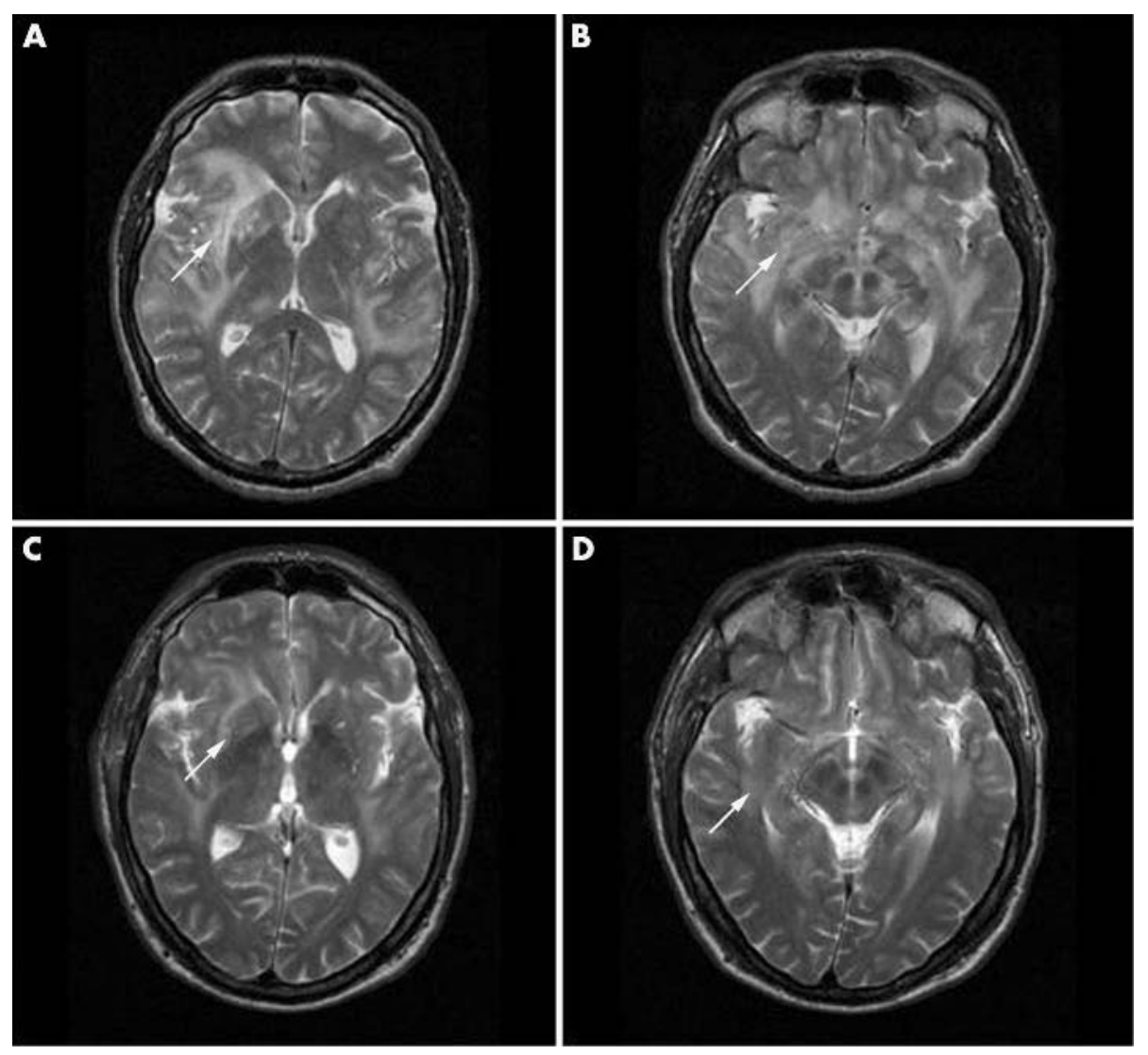

Figure 1 (A, B) Axial $T_{2}$ weighted fast spin echo MR images of the brain show increased signal intensity in the bilateral white matter and basal ganglia (arrows). (C, D) Follow up MRI shows a dramatic improvement of the white matter and basal ganglia abnormalities only 8 weeks after starting treatment.

Treatment consisting of intravenous methylprednisolone (3 days, $1 \mathrm{~g} /$ day), cyclophosphamide monthly $\left(750 \mathrm{mg} / \mathrm{m}^{2}\right)$, and haloperidol resulted in an impressive and sustained clinical and radiological improvement after 6-8 weeks (fig l). As evaluated by a psychiatrist and a neurologist, he no longer had psychosis, and his severe headache was relieved. He

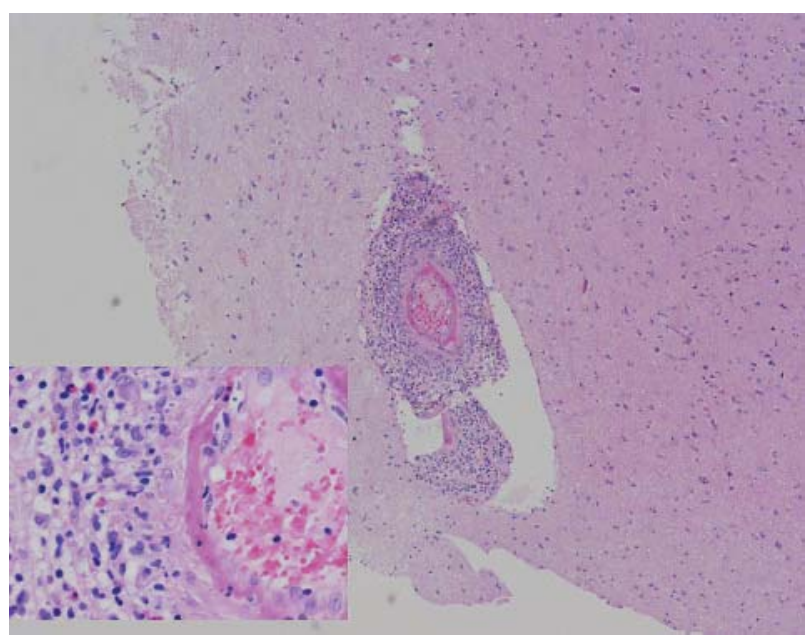

Figure 2 A cerebral biopsy specimen was taken from the right parietal hemisphere, leptomeninx, and cortex (original magnification $\times 200$ and $\times 40$ ). Severe histopathological signs of cerebral vasculitis in the cortex and leptomeninx can be seen, consisting of a diffuse mononuclear cell infiltrate through the whole vessel wall with fibrinoid necrosis in the presence of a normal cerebral angiogram of the same hemisphere. received another two methylprednisolone pulses at weeks 3 and 7 after starting treatment while continuing to receive prednisone $20 \mathrm{mg} /$ day by mouth. Cyclophosphamide pulses will be repeated monthly for 6 months and then every 3 months until he completes 2 years of treatment.

\section{DISCUSSION}

This patient had cerebral vasculitis as a primary manifestation of NPSLE based on psychosis, an earlier episode of polyarthritis, histopathological findings, positive ANAs, antidsDNA antibodies, and antiphospholipid antibodies (aPLs). Active SLE as reflected by systemic organ involvement was notably absent, which made a differential diagnosis with other cerebrovascular events appropriate. This patient is a middle age man who was receiving acenocoumarol because of amaurosis fugax and had low titres of ANAs and antidsDNA, all of which is compatible with a low risk profile to develop (NP)SLE. Therefore, we performed a brain biopsy, which clearly demonstrated vasculitis. Cerebral vasculitis in SLE is rare and its incidence in postmortem studies does not reach $10 \% .{ }^{1-3}$ Various pathological mechanisms like ischaemic and haemorrhagic events, white matter abnormalities due to aPLs, accelerated atherosclerosis, small vessel vasculopathy, and thromboembolic processes can all play a part. Based on previous studies, it might be argued that aPLs had a role in direct neuronal damage and in the pathogenesis of endothelitis in this patient, although this has not been proved. ${ }^{45}$ Cross reactivity between a subset of anti-DNA antibodies with $N$-methyl-D-aspartate type receptors in SLE supports the notion of shared antigenic target hypothesis as a possible underlying mechanism. ${ }^{6}$ 
No "gold standard" diagnostic test is available at present. Various attempts to link the pathogenesis with sensitive and specific tests have failed so far. Serum or CSF markers to detect NPSLE are lacking. MRI findings correlate with clinical manifestations only with a moderate sensitivity. Angiography may be normal if predominantly small vessels are affected. A recent European survey showed a high degree of perceived attention for cerebral angiography as a diagnostic tool for cerebral vasculitis. ${ }^{7}$ This patient clearly demonstrates that a normal angiograph cannot rule out fulminate cerebral vasculitis. Despite the low risk of complication, a brain biopsy is usually not needed unless primary cerebral vasculitis is suspected. However, a combination of clinical, serological, and imaging data usually has sufficient diagnostic value and can be used to make the diagnosis in order to institute adequate immunosuppressive treatment. $^{8-10}$ This case report demonstrates that cerebral vasculitis as demonstrated by brain biopsy is a primary and early manifestation of NPSLE.

\author{
Authors' affiliations \\ A T Rowshani, P Remans, P P Tak, Division of Clinical Immunology and \\ Rheumatology, Department of Internal Medicine, Academic Medical \\ Centre, University of Amsterdam, The Netherlands \\ A Rozemuller, Department of Pathology, Academic Medical Centre, \\ University of Amsterdam, The Netherlands \\ Correspondence to: Dr A T Rowshani, Academic Medical Centre, \\ University of Amsterdam, Division of Clinical Immunology and \\ Rheumatology, Department of Internal Medicine, PO Box 22700, 1100 \\ DE Amsterdam, The Netherlands; T.Rowshani@amc.uva.nl
}

Accepted 27 October 2004

\section{REFERENCES}

1 Koerner C, Sommer C, Knauth M, Breitbart A, Wildemann B. Granulomatous cerebral vasculitis in systemic lupus erythematosus during systemic remission of disease. J Neurol 2000;247:722-4.

2 ACR. The American College of Rheumatology nomenclature and case definitions for neuropsychiatric lupus syndromes. Arthritis Rheum 1999;42:599-608.

3 Weiner DK, Allen NB. Large vessel vasculitis of the central nervous system in systemic lupus erythematosus: report and review of the literature. J Rheumatol $1991 ; 18: 748-51$

4 Chapman J, Cohen-Armon M, Shoenfeld Y, Korczyn AD. Antiphospholipid antibodies permeabilize and depolarize brain synaptoneurosomes. Lupus 1999:8:127-33.

5 Meroni PL, Raschi E, Camera M, Testoni C, Nicoletti F, Tincani A, et al. Endothelial activation by aPL: a potential pathogenetic mechanism for the clinical manifestations of the syndrome. J Autoimmun 2000;15:237-40.

6 DeGiorgio LA, Konstantinov KN, Lee SC, Hardin JA, Volpe BT, Diamond B. A subset of lupus anti-DNA antibodies cross-reacts with the NR2 glutamate receptor in systemic lupus erythematosus. Nat Med 2001;7:1189-93.

7 Scolding NJ, Wilson H, Hohlfeld R, Polman C, Leite I, Gilhus N. The recognition, diagnosis and management of cerebral vasculitis: a European survey. Eur J Neurol 2002;9:343-7.

8 West SG, Emlen W, Wener MH, Kotzin BL. Neuropsychiatric lupus erythematosus: a 10-year prospective study on the value of diagnostic tests. Am J Med 1995;99:153-63.

9 Baca V, Lavalle C, Garcia R, Catalan T, Sauceda JM, Sanchez G, et al. Favorable response to intravenous methylprednisolone and cyclophosphamide in children with severe neuropsychiatric lupus. J Rheumatol 1999;26:432-9.

10 Stojanovich L, Stojanovich R, Kostich V, Dzjolich E. Neuropsychiatric lupus favourable response to low dose i.v. cyclophosphamide and prednisolone (pilot study). Lupus 2003;12:3-7.

\section{C reactive protein: protecting from lupus in familial Mediterranean fever}

\section{S Ozen, A Bakkaloglu}

$C^{1}$ reactive protein (CRP), a member of the pentraxin family, is a widely measured acute phase reactant. CRP concentrations have been shown to be increased in familial Mediterranean fever (FMF), which is the most common autoinflammatory disorder around the world. ${ }^{1-3}$ Interestingly, CRP is not only increased during the attacks of FMF but in between the attacks as well. ${ }^{3}$ Serum amyloid A protein levels are also increased in these patients. ${ }^{4}$

We have observed in our paediatric registry of over 1000 patients with FMF that many rheumatic diseases such as vasculitis and juvenile arthritis accompany FMF; we suggested that this might be due to the increased inflammatory milieu in these patients. ${ }^{1}$ However, none of the patients had systemic lupus erythematosus (SLE). Conversely, none of our patients with SLE had associated FMF.

Again in a multicentre study including about 3000 Turkish patients, certain inflammatory diseases were markedly increased, whereas SLE was not. ${ }^{5}$

We suggest that this is because of the high levels of CRP in these patients. ${ }^{1}$ These molecules are known to play an important part in the removal of apoptotic material by binding to the exposed small nuclear ribonucleoprotein (snRNP) particles. CRP mediates the removal of apoptotic cells. $^{6}$ Defective disposal of the potential autoantigens presented in the apoptotic blebs is a contributory factor in the pathogenesis of SLE. CRP has also been shown to bind to snRNPs. ${ }^{7}$ Recently, Russell et al have shown that a polymorphism in the CRP gene associated with lower CRP levels was associated with antinuclear antibody formation and they suggested that reduced basal CRP expression predisposes to the development of SLE. ${ }^{8}$ The rarity of SLE in patients with FMF may yet be further indirect clinical evidence of the role of CRP in protection against autoimmune diseases.

On the other hand, Adebajo and Davis drew attention to the decreased prevalence of SLE in West Africa'; they suggested that increased tropical infections might be a protective factor in this case. ${ }^{9}$

FMF is a very common disease in people of the eastern Mediterranean. Protection against SLE was probably not the selective advantage of the mutated gene; however, the augmented acute phase response seems to offer these patients at least one advantage.

\section{Authors' affiliations}

S Ozen, A Bakkaloglu, Department of Paediatric Nephrology and Rheumatology, Hacettepe University Faculty of Medicine, 06100

Ankara, Turkey

Correspondence to: Professor S Ozen; sezaozen@hacettepe.edu.tr

Accepted 24 September 2004 


\section{REFERENCES}

1 Ozen S, Bakkaloglu A, Yilmaz E, Duzova A, Balci B, Topaloglu R, et al. Mutations in the gene for familial Mediterranean fever: do they predispose to inflammation? J Rheumatol 2003;30:2014-18.

2 Tunca M, Kirkali G, Soyturk M, Akar S, Pepys MB, Hawkins PN. Acute phase response and evolution of familial Mediterranean fever. Lancet 1999;353:1415.

3 Korkmaz C, Ozdogan $\mathrm{H}$, Kasapcopur O, Yazici H. Acute phase response in familial Mediterranean fever. Ann Rheum Dis 2002;61:79-81.

4 Duzova A, Bakkaloglu A, Besbas N, Topaloglu R, Ozen S, Ozaltin F, et al. Role of A-SAA in monitoring subclinical inflammation and in colchicine dosage in familial Mediterranean fever. Clin Exp Rheumatol 2003;21:509-14.
5 Tunca M, Akar S, Onen F, Ozdogan H, Kasapcopur O, Yalcinkaya F, et al. Familial Mediterranean fever (FMF) in Turkey: results of a nationwide multicenter study. Medicine (Baltimore) 2005;84:1-11.

6 Dieker JWC, van der Vlag J, Berden JHM. Deranged removal of apoptoic cells: its role in the enesis of lupus. Nephrol Dial Transplant 2004; 19:282-5.

7 Du Clos TW. C-reactive protein reacts with the U1 small ribonucleoprotein. J Immunol 1989;143:2553-9.

8 Russell Al, Cunninghame Graham DS, Shepherd C, Roberton CA, Whittaker J, et al. Polymorphism at the CRP locus influences gene expression and predisposes to SLE. Hum Mol Genet 2004;13:137-47.

9 Adebajo A, Davis P. Rheumatic diseases in African blacks. Semin Arthritis Rheum 1994;24:139-53.

\title{
Iron deficiency anaemia in chronic inflammatory rheumatic diseases: low mean cell haemoglobin is a better marker than low mean cell volume
}

\author{
J Francis, D Sheridan, A Samanta, F E Nichol
}

Ann Rheum Dis 2005;64:787-788. doi: 10.1136/ard.2004.025890

p on deficiency anaemia (IDA) is a common and complex problem in chronic inflammatory rheumatic diseases. The predominant cause of IDA is gastrointestinal blood loss, often due to drug treatment. However, asymptomatic colonic and gastric carcinoma may present with IDA and exclusion of these conditions is of prime concern

The British Society of Gastroenterology has recently revised the guidelines for the diagnosis and management of IDA in the general population. ${ }^{1}$ These guidelines use a combination of low haemoglobin, low mean cell volume (MCV), and low serum ferritin to diagnose IDA.

Diagnosing IDA in the presence of chronic inflammation as seen in rheumatoid arthritis, poses considerable difficulty because serum ferritin is an acute phase reactant and rises in the presence of inflammation. A further complicating factor in our population is that MCV tends to be spuriously raised as a result of disease modifying antirheumatic drug (DMARD) treatment-in particular, sulfasalazine, methotrexate, and azathioprine.

It has been suggested by Jolobe ${ }^{2}$ and Broin et al that low mean cell haemoglobin $(\mathrm{MCH})$ correlates better with low ferritin levels and hence is better than low MCV as an aid to identifying patients with IDA, though this is still not widely used in routine clinical practice.

This study aimed at investigating whether MCV or MCH in combination with serum ferritin could be used effectively in screening for IDA in our patients.

\section{METHODS AND RESULTS}

We undertook a retrospective study of our patients with chronic inflammatory rheumatic diseases who were receiving regular blood monitoring for second line treatment. Those who were anaemic (haemoglobin $<115 \mathrm{~g} / \mathrm{l}$ in women and $<130 \mathrm{~g} / \mathrm{l}$ in men, which are the lower limits of normal range of haemoglobin concentration for the local laboratory ${ }^{1}$ ) on at least two occasions at least 1 month apart, were identified from "drug monitoring records". Further, those who were "iron deficient" were identified from APEX (computerised laboratory results system) based on low serum ferritin $(<20 \mu \mathrm{g} / \mathrm{l})$, low MCV $(<80 \mathrm{fl})$, and low $\mathrm{MCH}(<27 \mathrm{pg})$.

A total of 1231 records were examined (patient characteristics are outlined in table 1). Three hundred and four $(24.7 \%)$ were found to be anaemic during a 12 month period.
Sixty eight of these (22.4\%) were identified as "definite IDA" ( serum ferritin levels $<20 \mu \mathrm{g} / \mathrm{l}$, identified as the lower limit of normal range for the local laboratory). Of these 68, 44 (65\%) had low MCV, but 56 (82\%) had low MCH levels ( $p=0.016$, Fisher's exact test). In 36 patients with "probable IDA" (serum ferritin levels $20-100 \mu \mathrm{g} / \mathrm{l}$ ), MCV was low in 14 $(39 \%)$, but $\mathrm{MCH}$ was low in $26(72 \%)(\mathrm{p}=0.004)$.

\section{DISCUSSION}

IDA is common and often difficult to identify accurately in patients with chronic inflammatory rheumatic diseases. Bone marrow aspiration remains the preferred test for its diagnosis, but has the disadvantage of being invasive. Thus, we are limited to using serological tests of iron stores, the best validated of which is serum ferritin, which is the most powerful test of iron deficiency. ${ }^{4}$

It has been proposed by Goddard et al that a serum ferritin concentration of $>100 \mu \mathrm{g} / \mathrm{l}$ excludes IDA in the presence of concurrent inflammation, malignancy, or hepatic disease. ${ }^{1}$ Further, though serum transferrin receptor assay can help to distinguish between the anaemia of chronic disease and iron deficiency, it is no better than serum ferritin. ${ }^{5}$ However, there are no widely accepted guidelines for the diagnosis and management of IDA in our patient population, which represent a unique subset of patients.

Our study shows that a higher proportion of patients with both "definite IDA" and "probable IDA" had a low MCH compared with a low MCV. Low MCH correlated better with iron deficiency than low MCV.

\begin{tabular}{|lc|}
\hline Table 1 Patient characteristics \\
\hline Age (years), mean (range) & 60 (22-82) \\
Sex (\%) & 92 \\
Female & 8 \\
Male & 76 \\
Rheumatological diagnoses (\%) & 12 \\
Rheumatoid arthritis & 8 \\
Psoriatic arthritis & 2 \\
Seronegative spondyloarthropathy & 2 \\
SLE & \\
Other & \\
\hline
\end{tabular}


We suggest that in chronic inflammatory arthropathies, if the haemoglobin is low, then MCH is a better marker of iron deficiency than MCV. We therefore propose that $\mathrm{MCH}$ in conjunction with serum ferritin is a better predictor of IDA in patients with chronic inflammatory rheumatic diseases.

\section{Authors' affiliations \\ J Francis, D Sheridan, A Samanta, F E Nichol, University Hospitals of Leicester NHS Trust, Leicester, UK}

Correspondence to: Dr J Francis, Department of Rheumatology, Infirmary Close, Leicester LE1 5WW, UK; james.francis@uhl-tr.nhs.uk

Accepted 1 September 2004

\section{REFERENCES}

1 Goddard AF, Mclntyre AS, Scott BB. Guidelines for the management of iron deficiency anaemia. British Society of Gastroenterology. Gut 2000:46(suppl IV):iv1-5

2 Jolobe OMP. Prevalence of hypochromia (without microcytosis) vs microcytosis (without hypochromia) in iron deficiency. Clin Lab Haematol 2000;22:79-80.

3 O Broin SD, Kelleher BP, McCann SR, Ryder RJ, Scott JM. The value of the erythrocyte indices as a screening procedure in predicting nutritional deficiencies. Clin Lab Haematol 1990;12:247-55.

4 Guyatt GH, Oxman AD, Ali M, Willan A, Mcllroy W, Patterson C. Laboratory diagnosis of iron-deficiency anaemia: an overview. J Gen Intern Med 1992; 7:145-53.

5 Pettersson T, Kivivuori SM, Siimes MA. Is serum transferring receptor useful for detecting iron-deficiency in anaemic patients with chronic inflammatory diseases? Br J Rheumatol 1994:33:740-4.

\title{
Reactivation of a latent precore mutant hepatitis $B$ virus related chronic hepatitis during infliximab treatment for severe spondyloarthropathy
}

\author{
D Wendling, B Auge, D Bettinger, A Lohse, G Le Huede, S Bresson-Hadni, E Toussirot, J-P Miguet, \\ G Herbein, V Di Martino
}

W report a case of hepatitis $\mathrm{B}$ virus (HBV) reactivaion following the use of anti-tumour necrosis factor $\alpha(\mathrm{TNF} \alpha)$ antibodies that illustrates the need for careful viral monitoring and pre-emptive antiviral treatment in such patients.

\section{CASE REPORT}

A 35 year old white woman presented with a history of chronic hepatitis B without an increase in serum alanine aminotransferase (ALT) or detectable HBV DNA by a hybridisation technique since its diagnosis (in 1993); she was thus considered to be an asymptomatic HBV carrier. Her serological status was as follows: hepatitis B surface antigen positive, hepatitis B e antigen negative, hepatitis B e antibody positive, suggesting HBV precore mutant. Her rheumatological history began in September 2001 with oligoarthritis, inflammatory low back pain, limitation of motion, and anterior chest wall involvement. Symptoms improved incompletely with non-steroidal anti-inflammatory drugs. Biological inflammation (erythrocyte sedimentation rate $62 \mathrm{~mm} / \mathrm{lst} \mathrm{h}, \mathrm{C}$ reactive protein $53 \mathrm{mg} / \mathrm{l}$ ), positive HLA-B27 typing, and sacroiliitis on $x$ ray examination completed the picture.

The patient did not respond to successive methylprednisolone boluses, sacroiliac injections of steroids, salazosulfapyridine, and methotrexate (15 mg/week) then associated with pamidronate infusions. No changes in transaminases or HBV DNA load were detected during this period.

Infliximab was started $(5 \mathrm{mg} / \mathrm{kg} /$ infusion at weeks 0,2 , and 6) in August 2003, while she continued to receive methotrexate and non-steroidal anti-inflammatory drugs, with good response (over 50\% improvement of the Bath Ankylosing Spondylitis Disease Activity Index (BASDAI)) and return to a normal $\mathrm{C}$ reactive protein.

Follow up showed a progressive increase in serum transaminases, together with an increase in HBV DNA load assessed by quantitative real time polymerase chain reaction
(TaqMan; fig 1), with persistent negativity of hepatitis B e antigen and positivity of hepatitis B e antibody. A $100 \mathrm{mg} /$ day course of lamivudine treatment was promptly started in January 2004, while continuing infliximab every 8 weeks. This was followed by return to normal transaminase level, and undetectable HBV DNA load.

\section{DISCUSSION}

In this case of severe spondyloarthropathy, anti-TNF $\alpha$ treatment was, as expected, efficacious for treatment of the disease, but was followed by the first episode of HBV reactivation associated with hepatic cytolysis. In this case, infliximab was probably the culprit. Firstly, our patient was an asymptomatic HBV carrier, without any increase in serum ALT recorded over a long follow up period. Secondly, although she received methotrexate, which may favour HBV reactivation through its immunosuppressive properties ${ }^{1}$ and induce subfulminant HBV reactivation after its withdrawal, ${ }^{2}{ }^{3}$ no change in HBV DNA load was seen during the 9 months of methotrexate monotherapy.

Although the mechanism involved in anti-TNF antibody induced HBV reactivation is not fully understood, it is well known that TNF $\alpha$ as well as interferon $\gamma$, is produced during the innate immune response in the liver ${ }^{4}$ and has antiviral properties by inhibiting the replication of HBV DNA. ${ }^{1}$ Moreover, inactivation of $\mathrm{TNF} \alpha$ mediated apoptosis of cytotoxic lymphocytes by anti-TNF $\alpha$ antibodies may account for more severe liver disease. ${ }^{56}$

Our report is consistent with previously published cases of HBV reactivation after the use of infliximab. ${ }^{17}$ In the first case, it occurred 16 months after starting infliximab for rheumatoid arthritis and was controlled with both lamivudine treatment and discontinuation of infliximab ${ }^{1}$; in two cases of Crohn's disease, reactivation of chronic hepatitis B occurred after withdrawal of infliximab. ${ }^{7}$ Conversely, in another case of severe ankylosing spondylitis with chronic hepatitis B, a 1 year course of infliximab and methotrexate 


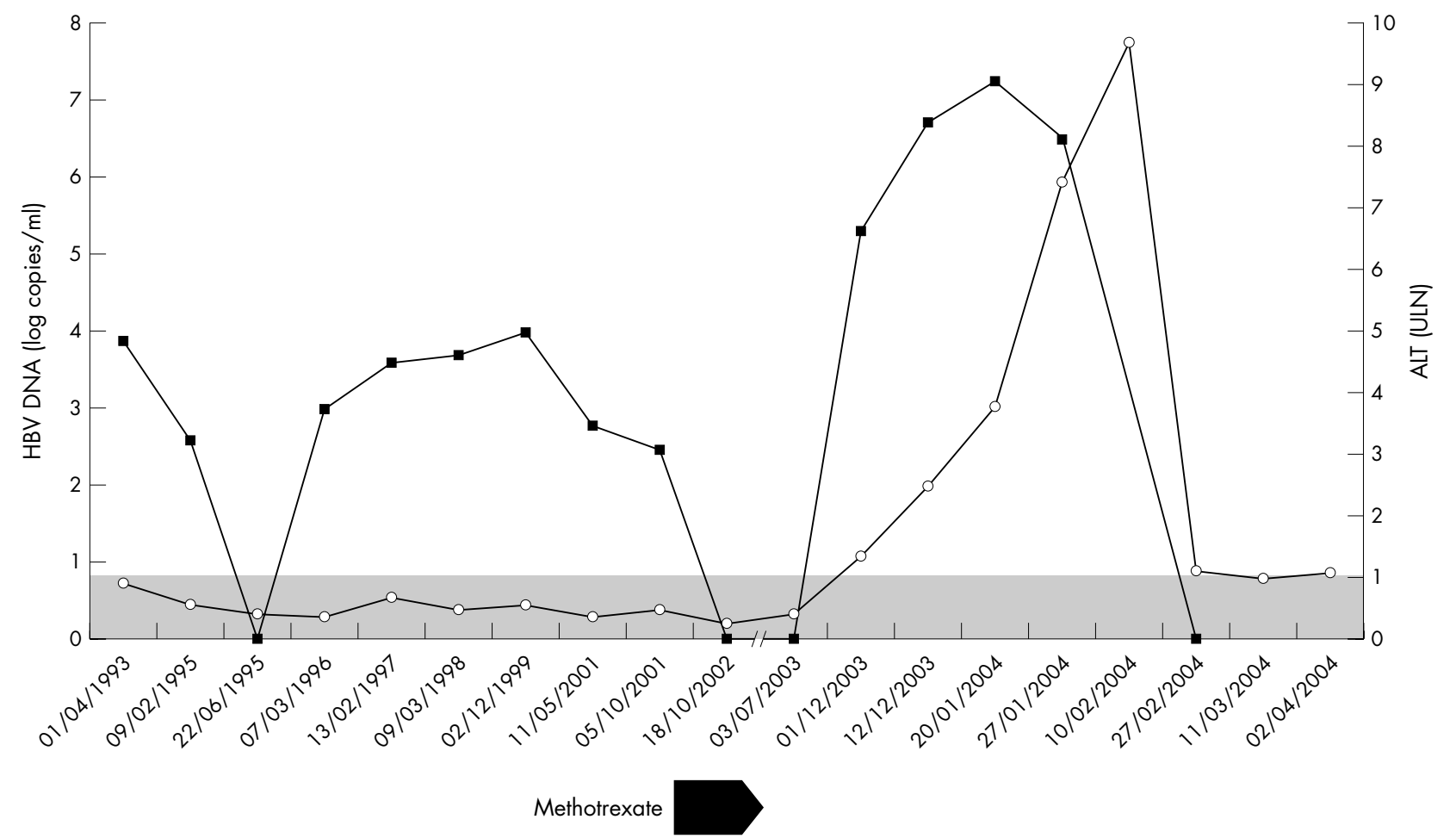

Infliximab

Lamivudine

Figure 1 Outcome of serum HBV DNA (black squares) expressed in log copies per millilitre, and serum ALT (white circles), expressed in times over the upper limit of normal range (ULN). Serum HBV DNA was quantified using an in-house real time polymerase chain reaction (TaqMan) with primers and probe located in the core region and conserved among HBV genotypes.

had no deleterious effect on liver biochemistry or HBV DNA load. It is noteworthy that in this latter case with favourable outcome, concomitant lamivudine treatment had been started 1 year before infliximab and controlled HBV replication. ${ }^{8}$ Hence, in HBV positive patients, further studies are needed to investigate the room and the timing for preventive lamivudine treatment. ${ }^{7}$ Moreover, pre-emptive lamivudine treatment (that is, started after the detection of a significant increase in serum HBV DNA load), as in our case, should also be able to control HBV reactivation in patients receiving infliximab, while continuing this treatment.

\section{ACKNOWLEDGEMENTS}

We thank Alain Bourgeois, Carine Dirand, and Dominique Thomasset for their technical help in the quantification of serum HBV DNA.

\section{Authors' affiliations}

D Wendling, B Auge, A Lohse, G Le Huede, E Toussirot, Service de Rhumatologie, Centre Hospitalier Universitaire, F-25030 Besançon, France

D Bettinger, G Herbein, Laboratoire de Virologie, Centre Hospitalier Universitaire, F-25030 Besançon, France

S Bresson-Hadni, J-P Miguet, V Di Martino, Service d'Hépatologie, Centre Hospitalier Universitaire, F-25030 Besançon, France
Correspondence to: Professor D Wendling, Department of Rheumatology, Jean Minjoz Hospital, University Teaching Centre, F-25030 Besançon, France; daniel.wendling@ufc-chu.univ-fcomte.fr

Accepted 24 September 2004

\section{REFERENCES}

1 Ostuni P, Botsios C, Punzi L, Sfriso P, Todesco S. Hepatitis B reactivation in a chronic hepatitis $B$ surface antigen carrier with rheumatoid athritis treated with infliximab and low dose methotrexate. Ann Rheum Dis 2003;62:686-7.

2 Narvaez J, Rodriguez-Moreno J, Martinez-Aguila MD, Clavaguera MT. Severe hepatitis linked to $B$ virus infection after withdrawal of low dose methotrexate therapy. J Rheumatol 1998;25:2037-8.

3 Ito S, Nakazono K, Murazawa A, Mita Y, Hata K, Saito N, et al. Development of fulminant hepatitis B (precore variant mutant type) after the discontinuation of low-dose methotrexate therapy in a rheumatoid arthritis patient. Arthritis Rheum 2001;44:339-42.

4 Parkin J, Cohen B. An overview of the immune system. Lancet 2001;357:1777-89.

5 Ando K, Moriyama T, Guidotti LG, Wirth S, Schreiber RD, Schlicht HJ, et al. Mechanisms of class I restricted immunopathology. A transgenic mouse model of fulminant hepatitis. J Exp Med 1993;178:1541-54.

6 Liu DX. A new hypothesis of pathogenetic mechanism of viral hepatitis $B$ and C. Med Hypotheses 2001;56:405-8.

7 Esteve M, Saro C, Gonzalez-Huix F, Suarez F, Forné M, Viver JM. Chronic hepatitis B reactivation following infliximab therapy in Crohn's disease patients: need for primary prophylaxis. Gut 2004;53:1363-5.

8 Oniankitan O, Duvoux C, Challine D, Mallat A, Chevalier X, Pawlotsky JM, et al. Infliximab therapy for rheumatic diseases in patients with chronic hepatitis B or C. J Rheumatol 2004;31:107-9. 


\title{
Use of herbal remedies and potential drug interactions in rheumatology outpatients
}

\author{
W Holden, J Joseph, L Williamson
}

Ann Rheum Dis 2005;64:790. doi: 10.1136/ard.2004.029991

A lthough the use of complementary and alternative therapies by rheumatology outpatients is increasingly acknowledged, ${ }^{1}$ little attention has been given to the safety of these treatments. Herbal and over the counter remedies are currently exempt from legislation governing conventional drugs such as quality control and postmarketing surveillance. The European Parliament has approved a directive proposed by the European Commission on traditional herbal medicines. ${ }^{2}$ Once this directive comes into force, legislation in the UK will follow and may lead to a registration scheme for traditional herbal remedies. It has been suggested that transitional licensing agreements will take at least $5 \frac{1}{2}$ years to establish. ${ }^{3}$ Until that time, it is probable that there will be an increase in the thousands of reports of adverse effects associated with herbal remedies, ${ }^{4}$ as well as more evidence of harmful interactions with conventional drugs. Rheumatology outpatients may be at particularly high risk of interactions with conventional medication because of high rates of polypharmacy and comorbidity.

Gingko biloba, devil's claw, ginger, and garlic may have antiplatelet or other anticoagulant effects, ${ }^{5-8}$ and have been associated with haemorrhagic complications. ${ }^{9}$ These remedies may therefore exacerbate the gastrointestinal bleeding risk of non-steroidal anti-inflammatory drugs (NSAIDS) or corticosteroids. Echinacea may be hepatotoxic ${ }^{8}$ and exacerbate this adverse effect of disease modifying antirheumatic drugs (DMARDS).

Our aim was to quantify the proportion of rheumatology outpatients who were taking herbal or over the counter remedies and to assess the number at potential risk of harmful interactions with their conventional rheumatological drugs. We also looked at the patients' perceived risk of the remedies they used and whether or not they had sought advice from a healthcare professional before starting the remedy.

Two hundred and thirty eight follow up rheumatology outpatients in three centres (Oxford, Swindon, Cirencester) completed an anonymous questionnaire about their rheumatological diagnosis, conventional drug treatment, and use of herbal and over the counter remedies during the past 6 months. Patients were asked whether they were aware of any side effects from the remedies, interactions with their prescription drug, and whether they had sought advice from a doctor or pharmacist before starting the remedy.

One hundred and five (44\%) patients had used herbal or over the counter remedies in the past 6 months. The most commonly used remedies were cod liver oil $(83 / 238$ (35\%)), glucosamine and/or chondroitin (50/238 (21\%)), and evening primrose oil $(26 / 238(11 \%))$. Twenty six $(11 \%)$ patients were taking remedies that might interact with conventional drugs. Five of $120(4 \%)$ patients receiving DMARDS were at increased risk of hepatotoxicity by also taking echinacea. Twenty four of $238(10 \%)$ patients were at increased risk of bleeding disorders by also taking ginkgo biloba, garlic, or devil's claw with NSAIDS or corticosteroids. Twenty four of 26 patients at risk of harmful interactions were unaware of this, and 10/26 had sought advice from a health professional before starting the remedy.

Doctors may not recognise potential adverse effects associated with herbal remedies, and patients may be reluctant to report either the use of herbal remedies or adverse effects. ${ }^{1}{ }^{10}$ Healthcare workers should remember to be particularly vigilant to ask about herbal remedies when taking a drug history. Both patients and prescribers need more education on the risks and potential interactions of these preparations.

\section{Authors' affiliations}

W Holden, Nuffield Orthopaedic Centre, Windmill Road, Headington, Oxford, UK

J Joseph, Nicosia Polyclinic, Nicosia, Cyprus

L Williamson, Great Western Hospital, Swindon, UK

Correspondence to: Dr W Holden; wendy.holden@noc.anglox.nhs.uk

Accepted 3 October 2004

\section{REFERENCES}

1 Rao JK, Mihaliak K, Kroenke K, Bradley J, Tierney WM, Weinberger M. Use of complementary therapies for arthritis among patients of rheumatologists. Ann Intern Med 1999;131:409-16.

2 Council of the European Union. Traditional Herbal Remedies Directive. 2001/ 83/EC. 2001.

3 Medicines and Healthcare Regulatory Agency. http://medicines.mhra.gov. uk/ourwork/licensingmeds/herbalmeds/herbalmeds.htm.

4 Edwards R. Monitoring the safety of herbal remedies. WHO project is under way. BMJ 1995;311:1569-70.

5 Chung KF, Dent G, McCusker M, Guinot P, Page CP, Barnes PJ. Effect of a ginkgolide mixture (BN 52063) in antagonising skin and platelet responses to platelet activating factor in man. Lancet 1987;i:248-51.

6 Srivastava KC. Evidence for the mechanism by which garlic inhibits platelet aggregation. Prostaglandins Leukot Med 1986;22:313-21.

7 Argento A, Tiraferri E, Marzaloni M. [Oral anticoagulants and medicinal plants. An emerging interaction]. Ann ltal Med Int 2000;15:139-43.

8 Miller LG. Herbal medicinals: selected clinical considerations focusing on known or potential drug-herb interactions. Arch Intern Med 1998; 158:2200-11

9 Rose KD, Croissant PD, Parliament CF, Levin MB. Spontaneous spinal epidural hematoma with associated platelet dysfunction from excessive garlic ingestion: a case report. Neurosurgery 1990;26:880-2.

10 Perharic L, Shaw D, Murray V. Toxic effects of herbal medicines and food supplements. Lancet 1993;342:180-1. 


\title{
Anti-cyclic citrullinated peptide antibodies in patients with primary Siögren's syndrome
}

\author{
G J Tobón, P A Correa, J-M Anaya
}

Ann Rheum Dis 2005;64:791-792. doi: 10.1136/ard.2004.029603

$\mathrm{P}$ rimary Sjögren's syndrome (pSS) is an autoimmune late onset disease characterised mainly by sicca symptoms. Lymphocytic infiltrate of the minor salivary glands and the presence of autoantibodies are the hallmarks of disease. ${ }^{1}$ The spectrum of pSS extends from an organ-specific autoimmune disorder (autoimmune exocrinopathy) to a systemic process that may involve the musculoskeletal system, leading to arthralgias and arthritis. In the latter case differential diagnosis with other autoimmune diseases like rheumatoid arthritis (RA) is a challenge.

In these situations, specific antibodies may be useful for making a correct diagnosis and, consequently, guide treatment. Anti-cyclic citrullinated peptide (anti-CCP) antibodies have been shown to be a specific marker for the diagnosis of RA. ${ }^{2}$ They bind to determinants rich in the unusual amino acid, citrulline, generated by deamination of arginine. ${ }^{3}$ We have read the recent article by Gottenberg et al, ${ }^{4}$ in which a 7.5\% prevalence of anti-CCP antibodies in 134 French patients with pSS was reported. Here, we describe a similar experience in Colombian patients with pSS.

We evaluated 53 patients who fulfilled the classification criteria of the American-European Consensus Group for pSS, ${ }^{5}$ and 79 patients with RA fulfilling the American College of Rheumatology classification criteria, ${ }^{6}$ of whom nine had secondary SS to RA. All patients with SS had a minor salivary gland biopsy disclosing a lymphocytic infiltrate with a focus score $>1$. Demographics and cumulative clinical and laboratory manifestations over the course of disease for the patients with SS were obtained and classified according to the terminology proposed by Oxholm et al. ${ }^{7}$ No patient with pSS met the RA classification criteria.

Anti-CCP antibodies were determined by enzyme linked immunosorbent assay (ELISA) using the anti-CCP2 kit QUANTA lite (INOVA Diagnostics Inc, San Diego, CA, USA). Levels above $60 \mathrm{IU}$ were considered positive. Five (9\%) patients with pSS tested positive for anti-CCP antibodies, and table 1 shows their main characteristics. Demographic and clinical characteristics of these five patients were not significantly different from those with pSS who were negative for anti-CCP antibodies, including articular involvement (arthralgias and/or arthritis). It should be noted that their long duration of disease (12.6 (7) years) together with a lack of erosions on $x$ ray examination do not support a diagnosis of RA. Sixty six (84\%) patients with RA were positive for anti-CCP antibodies $(\mathrm{p}<0.001)$; clinical and immunogenetic characteristics of these patients are described elsewhere. ${ }^{8}$ Six of nine $(67 \%)$ patients with secondary SS to RA tested positive for anti-CCP antibodies.

Our results indicate a low prevalence of anti-CCP antibodies in pSS. However, an anti-CCP positive test in patients with suggestive SS does not rule out the diagnosis of pSS, even in the presence of articular involvement. In addition, a positive anti-CCP test in patients with pSS is not necessarily a risk for articular involvement or development of RA. Further studies are warranted to elucidate the role of anti-CCP antibodies in pSS.

\section{Authors' affiliations}

G J Tobón, P A Correa, J-M Anaya, Corporación para Investigaciones Biológicas, Clínica Universitaria Bolivariana, Medellín, Colombia

Correspondence to: Dr J-M Anaya; janaya@cib.org.co

Accepted 9 October 2004

\section{REFERENCES}

1 Anaya JM, Talal N. Sjögren's syndrome comes of age. Semin Arthritis Rheum 1999;28:355-9.

2 Schellekens GA, Visser $H$, de Jong BAW, van de Hoogen FHJ, Hazes JMW, Breedveld FC, et al. The diagnostic properties of rheumatoid arthritis antibodies recognizing a cyclic citrullinated peptide. Arthritis Rheum 2000:43:155-3.

3 Bizarro N, Mazzanti G, Tonutti E, Villalta D, Tozzoli R. Diagnostic accuracy of the anti-citrulline antibody assay for rheumatoid arthritis. Clin Chem 2001;47:1089-93.

4 Gottenberg JE, Mignot S, Nicaise-Rolland P, Cohen-Solal J, Aucouturier F, Goetz J, et al. Prevalence of anti-cyclic citrullinated peptide and anti-keratin antibodies in patients with primary Sjögren's syndrome. Ann Rheum Dis 2005;64:114-17. doi:10.1136/ard.2003.019794 [published Online First 1 July 2004].

5 Vitali C, Bombardieri S, Jonsson R, Moutsopoulos HM, Alexander EL, Carsons SE, et al. Clasification criteria for Sjögren's syndrome. A revised

Table 1 Clinical and immunological features of patients with pSS with anti-CCP antibody

\begin{tabular}{|c|c|c|c|c|c|c|c|c|c|c|c|}
\hline $\begin{array}{l}\text { Patient } \\
\text { No }\end{array}$ & $\begin{array}{l}\text { Age } \\
\text { (years) }\end{array}$ & $\begin{array}{l}\text { Disease } \\
\text { duration } \\
\text { (years) }\end{array}$ & $\begin{array}{l}\text { Anti-CCP } \\
\text { antibodies } \\
\text { (IU/ml) }\end{array}$ & $\begin{array}{l}\text { Synovitis } \\
\text { (Y/N) }\end{array}$ & $\begin{array}{l}\text { Systemic } \\
\text { manifestation }\end{array}$ & $\begin{array}{l}\text { Serum } \\
\operatorname{lgG} \\
\lg / \mathrm{l})\end{array}$ & RF & Anti-Ro & Anti-La & $\begin{array}{l}\text { Focus } \\
\text { score }>1\end{array}$ & $\begin{array}{l}\text { ACR criteria } \\
\text { for RA } \\
\text { (n) }\end{array}$ \\
\hline 1 & 66 & 9 & 137 & $\mathrm{~N}$ & $\begin{array}{l}\text { Arthalgia, } \\
\text { Raynaud's } \\
\text { phenomenon }\end{array}$ & ND & - & + & - & + & 0 \\
\hline 2 & 59 & 14 & 181 & $Y$ & Arthritis, thyroiditis & ND & + & - & - & + & 3 \\
\hline 3 & 37 & 6 & 185 & $\mathrm{~N}$ & $\begin{array}{l}\text { Raynaud's } \\
\text { phenomenon }\end{array}$ & ND & + & + & - & + & 1 \\
\hline 4 & 53 & 10 & 124 & $Y$ & Arthritis & 1.2 & + & - & - & + & 3 \\
\hline 5 & 82 & 24 & 171 & $\mathrm{~N}$ & $\begin{array}{l}\text { Arthralgia, skin } \\
\text { vasculitis, thyroiditis }\end{array}$ & 9.6 & + & - & - & + & 1 \\
\hline Mean (SD) & $59.4(16.6)$ & $12.6(7)$ & $159.6(27.4)$ & $2 / 5$ & & & $4 / 5$ & $2 / 5$ & $0 / 5$ & $5 / 5$ & \\
\hline
\end{tabular}

Anti-CCP, anti-cyclic citrullinated peptide antibodies; RF, rheumatoid factor; ACR, American College of Rheumatology; RA, Rheumatoid Arthritis; ND, not done. 
version of the European criteria proposed by the American-European Consensus Group. Ann Rheum Dis 2002;61:554-8.

6 Arnett FC, Edworthy SM, Bloch DA, McShane DJ, Fries JF, Cooper NS, et al. The American Rheumatism Association 1987 revised criteria for the classification of rheumatoid arthritis. Arthritis Rheum 1988;31:315-24.
7 Oxholm P, Asmussen K, Axéll T, Van Bïjsterveld OP, Jacobsson L, Konttinen Y, et al. Sjögren's syndrome: terminology. Clin Exp Rheumatol 1995;13:693-6.

8 Correa PA, Tobon GJ, Citera G, Cadena J, Schneeberger E, Camargo JF, et al. Anti-cyclic citrullinated peptide antibodies in rheumatoid arthritis: relation with clinical features, cytokines and HLA-DRB1. Biomedica 2004;24: 140-52.

\section{Brucellosis as a cause of carpal tunnel syndrome}

\section{G Pappas, S Markoula, S Seitaridis, N Akritidis, E Tsianos}

C arpal tunnel syndrome (CTS) is the commonest entrapment neuropathy, often idiopathic, and sometimes secondary to a variety of aetiologies, rarely infectious. We present three cases of CTS arising in the course of infection by Brucella melitensis, and responding to specific antibiotic treatment. As far as we know, these are the first reported cases implicating brucellosis in the pathogenesis of CTS.

\section{CASE REPORTS}

Brucellosis is endemic in northwestern Greece. Among the numerous cases diagnosed and treated in the past 2 years, three patients presented with clinical symptoms suggestive of CTS, unilateral numbness and tingling sensation in the distribution of the median nerve.

On clinical examination, all three patients had positive Tinel's and Phalen's signs, and history, clinical, and laboratory examination excluded other possible causes of secondary CTS. No other neurological complications were noted. The diagnosis was confirmed by nerve conduction studies which, in one of the patients, apart from sensory fibres, elicited also a mild delay in the distal motor latency. The diagnosis of brucellosis was based on a consistent clinical picture and positive serology (Wright's agglutination test $>$ l/ 320, and positive enzyme linked immunosorbent assay (ELISA) serology). The first patient concurrently exhibited generalised weakness, the second patient was considered to have chronic brucellosis with a relapse presenting with fever, arthritis, and malaise, and the third patient presented with relapsing fever and polyarthritis, affecting the wrist. All three patients reported that CTS symptoms presented concurrently with the symptoms attributed to the disease.

All three patients were treated exclusively for brucellosis, one with doxycycline and rifampicin, and two with doxycycline and ciprofloxacin. The patients reported resolution of the symptoms when treatment ended at 6 weeks, and were further evaluated 3 months later with no evidence of relapse. Repeat nerve conduction studies were normal.

\section{DISCUSSION}

Although CTS is the commonest entrapment neuropathy encountered, ${ }^{1-2}$ many aspects of its aetiology remain obscure. ${ }^{3}$ Often termed as idiopathic, CTS can none the less be attributed to a variety of underlying disorders and processes, ${ }^{4}$ while random reports of CTS secondary to infectious diseases $^{5-7}$ also exist.

Brucellosis remains a significant burden for many developing countries. Although the disease is usually readily diagnosed and treated, it can present with a variety of focal complications, or exhibit, especially if mistreated, a chronic course.
Neurological complications in the course of brucellosis are unusual. $^{8} \quad$ Peripheral neuropathy is rarely reported. $^{9}$ Entrapment neuropathies though have never before been reported in association with brucellosis.

Various pathogenic mechanisms can be proposed for the appearance of CTS in the course of brucellosis, as illustrated by the three cases we present. The first of our patients seemed to have acute brucellosis, with a concurrent flexor tenosynovitis, resulting in median nerve compression and CTS. The second patient had chronic brucellosis, which is characterised by granuloma formation, development of which in the median nerve canal might result in the evolution of CTS. The third patient presented with polyarthritis affecting the wrist, with the resulting inflammation presumably implicated in the pathogenesis of CTS.

There is no way of knowing whether the median nerve dysfunction was secondary to a local mononeuritis or peripheral neuropathy, and no tissue was obtained to confirm a pathological diagnosis of flexor tenosynovitis associated with Brucella. It would seem unreasonable to perform an invasive procedure for the sake of scientific curiosity, because our patients responded readily to antibiotic treatment.

We conclude by emphasising the importance of including brucellosis in the differential diagnosis of secondary CTS in countries where the disease is endemic, because the variety of its clinical presentation, both in the acute and chronic form of the disease, can often be troubling.

\section{Authors' affiliations \\ G Pappas, E Tsianos, Department of Internal Medicine, University Hospital of loannina, Greece}

S Markoula, Department of Neurology, University Hospital of loannina, Greece

S Seitaridis, Department of Orthopaedics, Metropolitan Hospital, Athens, Greece

N Akritidis, Department of Internal Medicine, General Hospital

"G. Hatzikosta" of loannina, Greece

Correspondence to: $\operatorname{Dr} G$ Pappas, Internal Medicine Department, University Hospital of loannina, 451 10, loannina, Greece; gpele@ otenet.gr

Accepted 9 October 2004

\section{REFERENCES}

1 Sternbach G. The carpal tunnel syndrome. J Emerg Med 1999;17:519-23.

2 Dawson DM. Entrapment neuropathies of the upper extremities. N Engl J Med 1993;329:2013-18

3 Gelberman RH, Hergenroeder PT, Hargens AR, Lundborg GN, Akeson WH. The carpal tunnel syndrome. A study of carpal canal pressures. J Bone Joint Surg (Am) 1981;63:380-3.

4 Michelsen H, Posner MA. Medical history of carpal tunnel syndrome. Hand Clin 2002; 18:257-68

5 Alguacil GF, Martinez M, Garcia B, de Paco M. The carpal tunnel syndrome as a form of presentation of tuberculosis. Rev Clin Esp 1994;194:653. 
6 Bruno KM, Farhoomand L, Libman BS, Pappas CN, Landry FJ. Cryptococcal arthritis, tendinitis, tenosynovitis, and carpal tunnel syndrome: report of a case and review of the literature. Arthritis Rheum 2002;47:104-8.

7 Brutus JP, Baeten Y, Chahidi N, Kinnen L, Ledoux P, Moermans JP. Atypical mycobacterial infections of the hand: report of eight cases and literature review. Chir Main 2001;20:280-6.
8 Shakir RA, Al-Din AS, Araj GF, Lulu AR, Mousa AR, Saadah MA. Clinical categories of neurobrucellosis. A report on 19 cases. Brain $1987 ; 110: 213-23$.

9 Al Deeb SM, Yaqub BA, Sharif HS, Phadke JG. Neurobrucellosis: clinical characteristics, diagnosis, and outcome. Neurology 1989;39:498-501.

\section{Polymorphism at position -308 of the tumour necrosis factor $\alpha$ gene and rheumatoid arthritis pharmacogenetics}

\section{J E Fonseca, T Carvalho, M Cruz, P Nero, M Sobral, A F Mourão, J Cavaleiro, D Ligeiro, I Abreu, M Carmo-Fonseca, J C Branco}

$\mathrm{T}$ he pharmacogenetic relevance of the tumour necrosis factor $\alpha(\mathrm{TNF} \alpha)$ gene has just begun to be investigated. There is only preliminary evidence that the -238 GG genotype is associated with unresponsiveness to conventional disease modifying antirheumatic drugs ${ }^{1}$ and that a combination of alleles $(-308 \mathrm{TNF} / \mathrm{TNF} 1$ and -1087 GG interleukin 10 ) is associated with good responsiveness to etanercept. ${ }^{2}$ In addition, Mugnier et al recently suggested that patients with rheumatoid arthritis (RA) with a TNF $\alpha-308$ GG genotype might, in the short term, be better infliximab responders than patients with AA or AG genotypes. ${ }^{3}$

To evaluate the influence of the polymorphism at position -308 of the TNF $\alpha$ gene in the long term response to infliximab, we performed a prospective study of 22 consecutive patients with RA who were given infliximab treatment. All patients fulfilled the American College of Rheumatology 1987 revised criteria for $\mathrm{RA}^{4}$ and had a Disease Activity Score in 28 joints (DAS28) $)^{5}$ persistently above 3.2 after treatment with methotrexate $20 \mathrm{mg} /$ week for 3 months, according to the guidelines of the Portuguese Society for Rheumatology. ${ }^{6}$

Patients were given intravenous infusions of $3 \mathrm{mg} / \mathrm{kg}$ infliximab at weeks $0,2,6$, and then each 8 weeks. Before each infusion patients were evaluated with a protocol, which included evaluation of the DAS28 and the Health Assessment Questionnaire (HAQ). ${ }^{7}$ Radiological evaluation (hands and feet) was performed at inclusion and after 1 year of follow up. A blinded observer (JEF) using the Sharp/van der Heijde method analysed radiographs. ${ }^{8}$ DNA was extracted from a blood sample and the TNF $\alpha$ gene polymorphism at position -308 was determined by polymerase chain reaction, according to Grove et al. ${ }^{9}$ Patients who had the AA or AG genotype were compared with those who had the GG genotype. Comparisons of the two groups were evaluated by Student's two tailed $t$ test. All patients gave informed consent and the Egas Moniz Hospital ethics committee approved the study.

Fifteen of the $22(68 \%)$ patients had the -308 GG genotype and $7 / 22(32 \%)$ patients the -308 AG genotype. No significant differences were found between the two groups for disease duration (AG: 5.7 (4.9) years and GG: 10.3 (7.1) years; mean (SD)), age of onset (AG: 47.9 (14.2) years and GG: 45.8 (11.1) years), baseline DAS28 (AG: 4.2 (1.3) and GG: $5.0(1.5)$ ), baseline modified Sharp score (AG: 97.7 (40.3) and GG: $97.8(67.2)$ ), and baseline HAQ (AG: 1.32 (0.51) and GG: $1.47(0.68)$ ). Two of the seven (29\%) AG patients were DR3 positive, whereas only one of 15 (7\%) GG patients was DR3 positive.

After 24.8 (11.5) months of treatment with infliximab, patients with the -308 GG genotype had a significantly better response than the patients with the -308 AG genotype. In fact, they had a decrease in the DAS28 score of -2.4 (0.6), whereas the -308 AG group had a slight increase in the DAS28 score of $+0.12(0.18)(\mathrm{p}<0.01)$. This difference was significant from the second month of treatment (fig 1). There was also a tendency for a better HAQ evolution in the -308 GG group (a decrease of -0.38 (0.74) in the GG group and an increase of $0.32(0.92)$ in the AG group; $\mathrm{p}=0.064)$. Curiously, there was no difference in the radiological outcome (both groups had a decrease in the modified Sharp score of, respectively, -1 (13.1) and -1 (15.7); NS).

Our observations show that the TNF $\alpha-308$ genotype AG is associated with sustained (over 1 year) high disease activity and functional degradation despite treatment with infliximab, in patients with RA refractory to conventional disease modifying antirheumatic drugs.

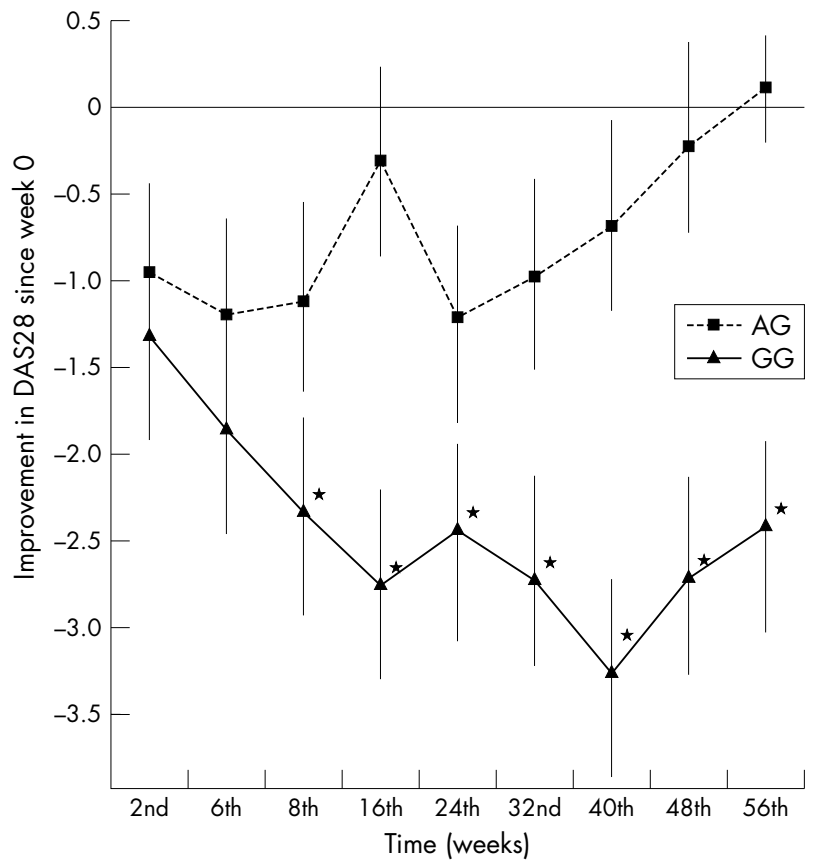

Figure 1 Mean improvement in DAS28 with infliximab treatment between first administration and the evaluation performed before each subsequent treatment in seven patients with RA with the TNF $\alpha-308$ genotype AG and 15 patients with RA with the TNF $\alpha-308$ genotype GG. Bars represent standard deviation; ${ }^{*} p<0.05$. 


\section{ACKNOWLEDGEMENT}

Work supported by Programa Operacional Ciência Tecnologia Inovação (POCTI), financed by the EU and by national funds of the MCES.

\section{Authors' affiliations}

J E Fonseca, M Cruz, P Nero, J C Branco, Rheumatology Unit, Egas Moniz Hospital, Lisbon, Portugal

J E Fonseca, T Carvalho, M Sobral, A F Mourão, J Cavaleiro, M CarmoFonseca, Institute of Molecular Medicine, University of Lisbon, Lisbon, Portugal

D Ligeiro, Centro de Histocompatibilidade do Sul, Lisbon, Portugal I Abreu, Departamento de Imunologia da Faculdade de Ciências Médicas, Lisbon, Portugal

Correspondence to: Professor J E Fonseca, Rheumatoid Arthritis Unit, Institute of Molecular Medicine, University of Lisbon, Faculdade de Medicina, Avenue Professor Egas Moniz, 1649-028 Lisbon, Portugal; jefonseca@netcabo.pt

Accepted 27 October 2004

\section{REFERENCES}

1 Fabris M, Di Poi E, Sacco S, Damante G, Sinigaglia L, Ferraccioli Gl. Tumor necrosis alpha gene polymorphism in rheumatoid arthritis patients treated with anti-TNF alpha agents: preliminary results. Reumatismo 2002;54:19-26.

2 Padyukov L, Lampa J, Heimbürger M, Ernestam S, Cederholm T, Lundkvist I, et al. Genetic markers for the efficacy of tumour necrosis factor blocking therapy in rheumatoid arthritis. Ann Rheum Dis 2003;62:526-9.

3 Mugnier B, Balandraud N, Darque A, Roudier C, Roudier J, Reviron D. Polymorphism at position-308 of the tumor necrosis factor $\alpha$ gene influences outcome of infliximab therapy in rheumatoid arthritis. Arthritis Rheum 2003;48: 1849-52.

4 Arnett FC, Edworthy SM, Bloch DA, McShane DJ, Fries JF, Cooper NS, et al. The American Rheumatism Association 1987 revised criteria for the classification of rheumatoid arthritis. Arthritis Rheum 1988;31:315-24.

5 Prevoo MLL, van't Hof MA, Kuper HH, van Leeuwen MA, van de Putte LBA, Van Riel PLCM. Modified disease activity scores that include twenty-eight-joint counts: development and validation in a prospective longitudinal study of patients with rheumatoid artritis. Arthritis Rheum 1995;38:44-8.

6 Consensus GEAR/SPR para utilização de DMARD biológicos. Acta Reum Port 2003;28:187-9.

7 Fries JF, Spitz PW, Kraines RG, Holman HR. Measurement of patient outcome in arthritis. Arthritis Rheum 1980;23:137-45.

8 van der Heijde D. How to read radiographs according to the Sharp/van der Heijde method. J Rheumatol 2000;27:261-3.

9 Grove J, Daily AK, Bassendine MF, Day CP. Association of a tumor necrosis factor promoter polymorphism with susceptibility to alcoholic steathepatitis. Hepatology 1997;26:143-5. 